\title{
Teaching about sustainable consumption with sustainable tools
}

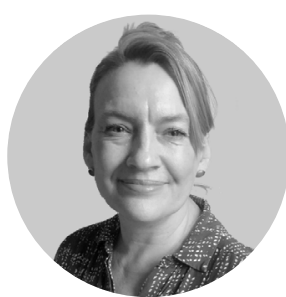

JANINE KNIGHT

UNIVERSITAT INTERNACIONAL DE CATALUNYA

janine@uic.es

$\mathrm{T}$ his paper focuses on the topic of sustainable consumption in order to support teacher trainers and future primary teachers in planning and integrating Education for Sustainable Development (ESD) competencies within their classes.

After considering different conceptual frameworks and studies pertinent to language learning, the paper shows how one project carried out between an English class in a university Education department and a local primary school in Barcelona, worked together to develop ESD competencies. As a form of action research, the projecte merged from an exploration of how language teachers in Higher Education contexts might focus on the content in terms of what is taught and how it is taught with respect to teaching and learning approaches, resource development and usage as sustainability issues. To support this aim, the paper describes how an English language learning project for pre-service teachers combined three aspects (approach, product and content) while focusing on sustainable consumption as part of an action-oriented, transformative pedagogy. The project was designed in order to develop ESD competencies for both trainee teachers of primary education and primary aged children, as well as supporting self-directed learning and life-long learning skills.

\section{KEYWORDS:}

Education for sustainable development (ESD), competencies, Task-based Language Teaching (TBLT), Sustainable consumption, collaborative learning, transformative pedagogy ste ste artículo se centra en el tema del consumo sostenible para dar apoyo a los formadores de maestros y futuros maestros de primaria en la planificación e integración de las competencias en Educación para el Desarrollo Sostenible (EDS) dentro de sus clases.

Tras considerar diferentes marcos conceptuales y estudios relativos al aprendizaje de idiomas, el documento muestra cómo un proyecto realizado entre una clase de inglés de un departamento de educación universitaria y una escuela primaria local de Barcelona trabajar juntos para desarrollar competencias de EDS. Como forma de investigación de acción, el proyecto surgió de una exploración de cómo los profesores de idiomas en contextos de educación superior se pueden centrar en el contenido en términos de lo que se enseña y cómo se enseña respecto a los enfoques de enseñanza y aprendizaje, desarrollo y uso de recursos. cuestiones de sostenibilidad. Para apoyar este objetivo, el documento describe como un proyecto de aprendizaje del inglés para maestros pre-servicios combinaba tres aspectos (enfoque, producto y contenido) al tiempo que se centraba en el consumo sostenible como parte de una pedagogía transformadora orientada a la acción. El proyecto se diseñó con el fin de desarrollarc ompetencias EDS tanto para maestros en formación de educación primaria como para niños de edad primaria, así como para apoyar las habilidades de aprendizaje autodirigido y de aprendizaje permanente.

PALABRAS CLAVE:

Educación para el desarrollo sostenible (EDS); competencias; Enseñanza de idiomas basada en tareas (TBLT); Consumo sostenible; aprendizaje colaborativo; pedagogía transformadora 


\section{Introduction}

$\mathrm{T}$ he 2030 Agenda for Sustainable Development (United Nations, 2015) outlines a clear need to integrate Education for Sustainable Development (ESD) principles into all levels of education, including primary schools. While access to quality education is explicitly formulated as a standalone Sustainable Development Goal (SDG) (SDG 4), there are also numerous education-related targets and indicators contained within other SDGs within the agenda. Examples include responsible consumption and production (SDG 12), which is focused on educating consumers, including students, on sustainable consumption and life styles. For the agenda to be fully realized, many propose that the agenda requires the need to adopt a transformative pedagogy that is action-oriented and which supports self-directed learning, participation and collaboration, problem-orientation, inter- and transdisciplinarity and the linking of formal and informal learning to the development of key sustainability competencies (Junyent, Cebrián and Mulà, 2018).

Furthermore, digital technologies, including static and mobile devices can conceivably play a role for teachers in supporting such a transformative pedagogy so that SD Goals can be achieved. This is because digital tools can be considered a "means of implementation" to achieve the SDGs by 2030 (International Telecommunications Union, 2017). Therefore, teaching about sustainability issues in additional language or social science classes is not merely a question about content and language but also highlights the role that digital tools can play as a potential "means" of supporting content and language development in a sustainable way. This can be useful to any educational programme that focuses on skills and knowledge development regarding both content and language including Content and Language Integrated learning (CLIL), English for specific purposes (ESP) and Content-based Instruction (CBI), amongst others. At a teacher and institutional "level" this may mean looking at digital tools not only as a means for reducing paper usage and waste, but also to re-use created teaching and learning products across people and contexts.

${ }^{66}$ For teachers to become transformative agents of change, not only to support their own but also children's ESD competencies development, conceptualisations of teaching (and by implication teachers' roles and views about what constitutes teaching) would also need to be revisited.'
While the "content" part of sustainable education that primary teachers are expected to teach are clearly outlined in many Primary School Curricula, including the curriculum in Catalonia, examples of how to consciously combine the "content" with "the means" are not explicitly developed. Tried and tested examples of how additional language learning classrooms might tackle sustainable development "content" have been show-cased for teachers to follow or draw inspiration from (e.g. Maley and Peachey, 2017). With respect to the "means", the role and considerations related to digital tools in language learning contexts towards sustainability issues have been highlighted in studies in Computer Assisted Language Learning (henceforth CALL) (Sanz, Levy, Blin and Barr, 2015). These studies highlight the importance of sustainable approaches and methodologies in relation to e-learning products and systems as conceivable "means" for attaining sustainable consumption practices in teaching and learning scenarios. Research on CALL and sustainability issues has therefore focused predominantly on the how rather than the what (learning contents) through CALL. However, no studies in CALL or practical cases for teachers of sustainable development exist (to the knowledge of this author) regarding how teachers might consciously combine both. That is to say, both the "means" and "content" in order to develop ESD competencies for sustainable consumption as well as through the use and production of e-learning products as sustainable (digital) approaches. This study aims to fill this gap by describing how an English language learning project for pre-service teachers, which aimed to combine all three aspects (approach, product and content), focused on sustainable consumption as part of an action-oriented, transformative pedagogy.

\section{Education for sustainable development, transformative pedagogy and pre-service teacher education}

In order for Education stakeholders including teachers, pre-service teachers, children, schools and teacher trainers to achieve the SDGs, specifically the goal of responsible consumption and production (SDG 12), working together, pooling and sharing resources and efforts, as well as minimizing waste, is arguably energy efficient and therefore a desirable aim. Furthermore, such an aim would require that educational institutions, including schools and universities, are in a position to facilitate this aim in the first instance. Achieving responsible consumption and production habits with respect to individuals may require these individuals and educational institutions to become agents of change. With respect to teachers, institutional and curricula level strategies may also need to be in place in teacher training courses in order for this change to happen. Moreover, for teachers to become transformative agents of change, not only to support their own but also children's ESD competencies development, conceptualisations of teaching (and by implication teachers' roles and views about what constitutes teaching) would also need to be revisited. There are three common views of what constitutes teaching: teaching 
as transmission, teaching as transaction, and teaching as transformation (Miller, 1996). Transmission is concerned with teaching as the act of transmitting knowledge from Point A (a teacher's head) to Point B (students' heads) in which the teacher is the dispenser of knowledge (Johnson, 2010). This conceptualization of teaching has been traditionally associated with Higher Education contexts, including Spain, because of the dominance of lectures for many of their teaching processes (Nygaard, Courtney and Holtham, 2011). Transaction on the other hand is focused on the process of creating situations whereby students are able to interact with the material to be learned in order to construct knowledge (Johnson, 2010). In primary and secondary schools this latter view of teaching is endorsed through the promotion of a constructivist philosophy whereby knowledge is not passively received; rather, it is actively constructed by students as they connect their past knowledge and experiences with new information (Santrock, 2004). Constructivism as a philosophy was endorsed by the Organic Act on the General Organisation of the Education System (Ley de Ordenación General del Sistema Educativo or LOGSE, 1990) and on which many teachers in primary and secondary schools within the public system are encouraged, through official educational websites such as xtec.cat, to base their teaching. The third conceptualization of teaching is Transformation. According to Johnson (2010), transformation pedagogy differs from transmission and transaction because teaching is the creation of conditions that have the potential to transform the learner on many different levels (cognitive, emotional, social, intuitive, creative, spiritual, and other). This teaching invites both students and teachers not only to discover their full potential as learners but also as members of society, and as human beings. Learning is said to have occurred when these experiences elicit a transformation of consciousness that leads to a greater understanding of and care for self, others, and the environment (Johnson, 2010). Because of this, transformative teaching conceivably offers the learners a holistic way in which they can transform themselves and others through the process of becoming social agents, both in and outside of the classroom, with regards to caring for the environment.

However, despite the declaration of good intentions and policy developments in Higher Education at the national, regional and international level, little has been achieved in terms of embedding ESD holistically in the curriculum (Cebrían and Junyent, 2015). One potential way to address this is by university teacher trainers taking transdisciplinary approaches to curriculum integration, which aims to dissolve the boundaries between conventional disciplines and organize teaching and learning around the construction of meaning in the context of real-world problems or themes. Transdisciplinary work moves beyond bridging divisions within academia to engaging directly with the production and use of knowledge outside of the academy (Toomey, Markusson, Adams and Brockett, 2015).

In a Higher Education context, programmes which combine language and content as a focus within the classes (such

\section{${ }^{66}$ Transformative teaching conceivably offers the learners a holistic way in which they can transform themselves and others through the process of becoming social agents, both in and outside of the classroom, with regards to caring for the environment.}

as CLIL, ESP and CBI) are perhaps an apt place for such transdisciplinary work. This is because they can be tailored to meet learners' specific professional needs and interests, focus on language use for real communication, and contents can be selected because of their relevance for these needs and interests (Hutchinson and Waters, 1987). Furthermore, there is a time imperative for trainee teachers to "learn by doing" (Dewey, 2011) as students have only four years to develop basic knowledge and competencies for a $21^{\text {st }}$ century classroom, that addresses $21^{\text {st }}$ century challenges, by the time they leave university.

In the context of pre-service teacher education, trainee teachers can be understood as both teachers-as-agents of change (in schools) as well as citizens-as-agents of change. Pre-service teachers also have beliefs and habits of consumption that may change during their own university education. Developing competencies for sustainable education amongst graduates is particularly critical to the development of sustainability literacy skills: the attributes and values that we need to survive and thrive in the $21^{\text {st }}$ century and build a more sustainable future (Stibbe, 2009). Developing these competencies is conceivably necessary for students to engage in personal and social change to support positive change in their workplace and personal lives (Sipos, Battisti and Grimm, 2008). Such competencies or skills can enable graduates (including pre-service teachers) to deal with sustainability as they need to use critical and creative thinking, problem-solving skills, action competence, collaboration and future thinking. This is so that they become empowered and globally-responsible citizens and professionals who can become active change agents (Fadeeva, Mochizuki and Wals, 2010).

Cebrián and Junyent (2015) propose that the use of certain types of pedagogies, teaching and learning approaches and strategies to foster transformation with respect to SDG goals are needed if the development of key sustainability competencies relating to pre-service teachers are to be 
achieved (Cebrián and Junyent, 2015). Pedagogies can be understood as the theories and practices that inform teaching strategies, teachers'actions, judgments and decisions. Based on research conducted on sustainability in Higher Education, they explored the learning outcomes and competencies that educational programs need to seek to develop in students for them to become change agents towards sustainability (Mochizuki and Fadeeva, 2010; Sipos, Battisti, and Grimm, 2008; Svanström, Lozano-García and Rowe, 2008). The review of this research by Cebrián and Junyent (2014; $2015)^{1}$ resulted in the creation of a theoretical framework of the professional competencies in ESD, comprising of seven key components. They propose that the framework can contribute to the development of key sustainability competencies. The components are as follows (Cebrián and Junyent, 2015, pp. 2771):

\section{Future/alternative scenarios visioning:}

Understanding the different scenarios, possible futures, promoting work with different visions and scenarios for alternative and future changes.

\section{Contextualizing:}

Taking into account the different dimensions of a problem or action, the spatial dimension (local-global) and the temporal dimension (past, present and future).

\section{Working and living with complexity:}

The ability to identify and connect the ecological, economic and social dimensions of problems. Generate the conditions for systems thinking in the school environment.

\section{Thinking critically:}

Creating the conditions for critical thinking to question assumptions and to recognize and respect different trends and views in different situations.

\section{Decision-making, participation and acting for change:}

moving from awareness to action; sharing responsibilities and engaging in joint action.

\section{Clarifying values:}

Values clarification and strengthening behaviour towards sustainability thinking, mutual respect and understanding of other values.

\section{Establishing a dialogue between disciplines:}

Developing teaching and learning approaches based on innovation and interdisciplinarity as well as manage emotions and concerns: promoting reflection on one's own emotions and as a means to reach a deeper understanding of problems and situations.
Given the important challenge that future teachers face regarding developing their own sustainability competencies, as well as competencies of the children they teach, a course that aims to develop both is conceivably needed. The challenge raises the question as to how trainee teachers might engage in such learning. The challenge also highlights the responsibility of teacher training programmes, and language learning courses within it, to address how potentially transformative education can be carried out. The question of "how" should therefore be explored even before a project or intervention can be measured as being "transformative" or not. This scenario would potentially benefit from research approaches that involve teachers acting to address an issue or a problem relating to a teacher's own practice in order to learn from that action. Action research fits such a scenario (Stringer, 2008).

Taking these issues into consideration, along with the stated challenges about developing sustainability competencies of teachers, the study aims to investigate how language course designers might address the need to teach: 1) content and 2) language - regarding aspects of sustainability, alongside incorporating 3) digital tools as sustainable means. This study fills this gap by presenting a project that sought to address these three aspects. The contribution to the field is in showing how all three aspects of sustainable consumption might be integrated in a project design for pre-service teachers with a view to develop sustainability competencies in a more holistic, multi-faceted way.

${ }^{66}$ Given the important
challenge that future
teachers face regarding
developing their own
ustainability competencies,
as well as competencies of
the children they teach, a
ourse that aims to develop
oth is conceivably needed.
The challenge raises the
question as to how trainee
teachers might engage in
such learning.




\section{The participants and context}

T

he project took place in a private university in Barcelona, Spain. The students carrying out the project were 32 first year students, studying on the degree for Primary and Pre-school Education in the faculty of Education. The students attended English language as a subject, once a week, lasting one academic year. The students were aged between 19 and 22 and their English language level was between B2 and $\mathrm{C} 1$ on the Common European Framework of Reference for Languages (Council of Europe, 2001). Before the course started, the course had undergone a review by teachers and managers. The outcome of which resulted in the content of the classes moving away from a general English focus (with a structured course book) to a project-based approach. It was deemed in the course review that such an approach and different content focus could address students' professional needs as future teachers more appropriately. This meant that projects needed to be created in line with this change. Four projects were designed as part of the new course, including "Developing online language materials and activities for primary children to learn English", "Corporate Social Responsibility", "Language learning tips from expert teachers" and "Sustainable Consumption". The latter project is the focus of this paper.

Participants in the project also involved an English teacher and children from a $2^{\text {nd }}$ year class of a primary school, so children aged 7-8. The school was a public (state) school in Barcelona and trainee teachers had carried out activities with children on previous occasions. The school had previously worked on issues of sustainable consumption in both explicit and implicit ways e.g. using recycling materials for art classes was a norm and children were taught not to use foil for the sandwiches at nursery level because it creates "a foil monster" that is not good for the planet. Children were also encouraged not to bring industrially baked products for their birthdays to class (e.g. cakes and biscuits) but rather, they could choose a special activity they want to do instead.

\section{Method}

$T$ he method used incorporated an Action research approach. Action research is based on an assumption that understanding is grounded in experience coupled with an analytic approach to evidence, followed by reflective integration (Reason and Bradbury, 2006). The research consisted of one cycle involving the steps of 1.study and plan; 2.take action; 3.collect and analyse evidence and 4.reflect. The reflection was undertaken with a "critical friend" in the form of a school-based English teacher.

\section{A transdisciplinary Sustainable Consumption project: the how, the what}

$\mathrm{n}$ response to the research question as to how a language course designer in a Higher Education context can combine the three aspects of content, language and means (or the what with the how) the project was developed with this triple focus in mind. This is illustrated in Figure 1.
Phase 1 - Approaches used by teacher trainer:

- Products created by pre-service teachers:

- Content (and language): waste, energy and pollution
Computer assisted language learning (CALL), Task-based, Project-based learning

1) digital teaching and learning resources

2) an outline of the task sequence alongside

3) shared digital glossary of terms pertaining to sustainable consumption in English, Catalan and Spanish.
Potential change agents:

Language and content teacher and pre-service teachers
- Product:

- Content (and language):
Task-based learning that incorporated problem-based learning for children (decision making task) involving pre-task, task and post task stages

Children's posters of pictures of actions and products, classified as "more sustainable" and "less sustainable"(created product)
Potential change agents: Language and content teacher, children and in-service school

The concepts the children learnt, evidenced in their ability to classify the image cards correctly as well as the language learnt and used by the children orally "more sustainable/less sustainable" plus the understanding and use of related lexical items.

Phase 3 - Product:

Box of resources and lesson plans on "waste", "pollution" and "energy"

Potential change agents:

The creation of a blog, making the lessons plans and resources Other in-service language (or freely available to teachers (https://betterworldschools.com/) 
Figure 1 represents part 2 of the action research cycle after studying frameworks and reading extensively and planning, considered to be part 1 . While phases 1 and 2 formed part of the initial "take action" in part 2 of the action research cycle, phase 3 was added after the reflection at the end of the action research cycle.

As shown in Figure 1, there were initially two phases of the project and both phases aimed to address sustainable consumption holistically by considering approach, product and content (as sustainability issues) as part of an actionorientated, transformative pedagogy. The two phases relate to how the project was implemented, with phase 1 pertaining to the work with the pre-service teachers at the university and phase 2 connected to working with the children in the school. Phase 3 emerged from the results from both phases and refers to the creation of a box of resources and lesson plans on waste, pollution and energy that were piloted in the school in phase 2. The idea for the creation of the box and a blog emerged after phase 2 in order to make these resources freely available to other teachers of English and schools in Barcelona. Therefore, the products created in phase 1 and piloted in phase 2 became reusable products in phase 3 .

\section{Phase 1 at the university}

Phase 1 took place at the university and classes lasted one and a half hours per week. The subject "Anglès 1" (English 1) was taught to pre-service teachers in their first year of study and took a predominantly project-based and taskbased approach to the course content and allowed for the flexibility of incorporating other approaches such as CALL.

\section{Phase 1: Approach(es)}

As aforementioned, the project was designed to use CALL, specifically pre-existing video resources on YouTube among other internet-based resources and Google Docs for collaborative work that students could share with the teacher, each other and potential teachers in schools after they have left the university. Levy, Gimeno, Barr and Blin (2015) noted collaboration within institutions and beyond as a key feature of sustainable CALL as well as the re-use of the materials and tools.

In addition, alongside a focus on content and language, a task-based learning approach was integrated. This was conceived as being apt for an action-orientated, transformative pedagogy because of a number of features task-based learning has. It focuses on 1) providing opportunities for students to exchange information with a focus on meaning, not a specific form or pattern/structure; 2) prescribing a clear purpose for learners through an outcome at the end of different tasks (such as making a You Tube video tutorial, finding a solution for a problem or writing an email requesting information); 3)resulting in an outcome that can be shared with others and 4) relating to real world activities (Ellis, 2009).

For the purposes of the project in phase 1, the teacher trainer was interested in the following: that the trainee teachers researched and talked about sustainable consumption issues (focus on meaning); that they used English (talking, researching/reading, writing) in order to learn more about sustainable consumption and that they created the activitiesand resources for the children (clear purpose and final product). In addition, the aims of the project focused on its transferability (shared with others in the class) and finally, that what they were doing constituted an authentic activity that was relevant, useful to them and that they could (re)use in their future profession.

While there are many task types (see Nunan, 1989 for overview) such as role-play and information gap, a classification/decision making task was chosen for the project. This reflected Cebrián and Junyent's (2015) point that the process of Decision-making involves participation and acting for change: moving from awareness to action; sharing responsibilities and engaging in joint action. After this task type was explained to trainee teachers, and examples given, trainee teachers were asked to develop the pre-task, task preparation (activities leading up to the task) and post task activities following a Task-Based Methodology Framework adapted from Willis $(1996)^{3}$. This was communicated through the teacher's introduction to the project and instructions (Appendix A). While the task type was pre-decided for them, trainees could choose what decisions children could make through the selection or creation of image cards e.g. lights on/lights off. In addition, they could create other pretask, task preparation and post task-activities other than the examples given to them.

\section{Phase 1: Product}

The product in this phase was facilitated through the use of Google drive and Google docs which all students had access to because the university was signed up to "G Suite for Education" which offers email service, documents for shared collaboration and a cloud-based drive where such documents can be stored. "The product" required from trainee teachers were the 1) teaching and learning resources and 2) an outline of the task sequence alongside a 3) shared glossary of terms pertaining to sustainable consumption in English, Catalan and Spanish. The glossary was created in order that trainee teachers were clear of the key concepts involved. The process of creating the glossary also meant that the translation of these concepts were researched, discussed, shared with each other and added to collaboratively. It was also envisaged by the teacher trainer that the completed glossary might be something that could be shared with other schools in Barcelona (which formed part of phase 3 of the project $)^{4}$. These tools facilitated that the project be carried out in a paper-free way as much as possible. Students were encouraged to use their own laptops or mobiles to complete the project. The teaching and learning materials that the 
trainee teachers produced (image cards) were to be used in phase 2 (pilot school context), which involved a selection and printing (and laminating for re-use) for stage 2. The final products were Google documents in a shared Google Drive which students, the teacher trainer, translator at the university (as checker) and school teachers had access to.

\section{Phase 1: Content}

The written project guidelines were made available to trainee teachers initially with some copies on paper in class. One paper copy of project guidelines was made for each group of 3 students (Appendix A) but was also made available online in the Google Drive.

With respect to content, the project was based on developing three of the seven key components that Cebrián and Junyent (2014; 2015) outline, all be it at a basic level and which supported the content development or the what of the project. These three components were:

1. Working and living with complexity: the ability to identify and connect the ecological, economic and social dimensions of problems. Generate the conditions for systems thinking in the school environment.

\section{Decision-making, participation and acting for change:} moving from awareness to action; sharing responsibilities and engaging in joint action.

3. Future/alternative scenarios visioning: understanding the different scenarios, possible futures, promoting work with different visions and scenarios for alternative and future changes.

Furthermore, the "conceptual model of sustainability within the context of consumption" (Luchs and Miller, 2015) was used to develop the contents by supporting the teacher trainer to encourage trainee teachers to focus on waste, energy and pollution (concerning the environment).

The main decision-making task required that trainee teachers (and children in phase 2) were positioned as problem solvers and change agents who could make everyday decisions that were more or less sustainable when compared with other decisions. This aimed at helping trainee teachers identify and connect the ecological with the social dimensions (component 1). The decision-making about everyday products/usage/ actions was also used to encourage participation and action for change (component 2) and future/alternative scenarios were aimed to be developed through discussion about alternatives e.g. "Is bamboo a sustainable source?", which emerged during the project work and was further developed in phase 2 (Appendix B).

In addition to the use of conceptual frameworks to support the development of content across the project, language of the content (vocabulary focus of the task) and language to carry out the main task (to classify) also needed to be planned for because trainee teachers were on a language learning course. The language focus of the project for trainee teachers was the learning of the key vocabulary associated with sustainable production, purchase, usage and disposal (Luchs and Miller, 2015) such as "pollution" from car use, "plastic bag" purchase and "recycling". These were the same lexical items that the children were expected to understand and work on at school in phase 2. In addition, the decision making task meant that the structures "... is more sustainable than" and "...is less sustainable than" were also needed for task completion and therefore the trainee teachers needed to know these English structures for comparing image cards of actions/products/usage.

\section{Phase 2 at the school}

Phase 2 took place at the school. Initially, the pre-service teachers were going to carry out the task sequence but this did not happen due to a conflict with curriculum restraints ${ }^{5}$. Therefore, the teacher trainer carried out the final task sequence with the children.

\section{Phase 2: Approach(es)}

The class with the children followed a task-based approach involving activities for pre-task, task preparation, task and post-task stages. These activities were created by the teacher trainer but the resources (image cards) for the main task were those chosen and/or created by the trainee teachers and the main task of decision making and classifying was maintained.

In the pre-task children were posed with three problems on flashcards (problem 1, problem 2, problem 3) which they had to match with the corresponding images to and guess the key concept/word (pollution, waste, energy). This reflected orientation to a problem in order to develop sustainability competencies. The pre-task activities also facilitated an exchange of information and related to the real world as children shared their own experiences, habits and thought processes relating to their own sustainable or unsustainable actions, e.g. using a flask instead of a single use water bottle. The task preparation invited children to decide as a whole group as to whether an image card (representing an object or habit) was "more or less sustainable". This was modelled by the teacher using a pre-prepared poster with "more sustainable" and "less sustainable" as titles. The children had to classify these cards as a whole group. After the task preparation stage, the task consisted of the children working in pairs to classify their own cards: deciding and then gluing their own image cards according to whether they thought the objects/actions were more or less sustainable. They could decorate it accordingly. The post task stage asked children to draw their own sustainable Barcelona (Appendix B) and complete a word search with the key words used in the session e.g. waste. 


\section{Phase 2: Product}

The task required that the children created a poster of "more sustainable" and "less sustainable" actions/usage/ products, using the image cards in envelopes. The learning materials for children to make the poster were a blank poster sheet, image cards in envelopes, pens and glue. Children had to work in groups of two or three and choose which card to discuss and decide on it together thus supporting "self-directed learning, participation and collaboration" as a means of developing key sustainability competencies (Junyent, Cebrián and Mulà, 2018).

The other products that the children produced in the posttask involved a word search of the key lexical items that they had heard and used as well as a "My sustainable Barcelona" frame whereby they could envisage future, alternative scenarios (Cebrián and Junyent, 2015, pp. 2771). The children's product was supported by the work undertaken in phase 1 , namely the teaching and learning materials (selected printed images from the internet) and a lesson plan mapped to the Common European Framework of Languages (Council of Europe, 2001) (Appendix C) and "problem flashcards" (Appendix D) .

\section{Phase 2: Content}

The content can be understood as the concepts the children learnt, evidenced in their ability to classify the image cards correctly as well as the language learnt and used by the children (structures "more sustainable/less sustainable" plus the lexical items).

After phase 2 it seemed fitting to identify a way to make the resources and lesson plans available for other teachers and learners to re-use freely. This led to Phase 3 or project re-use.

\section{Phase 3: Project re-use and dissemination}

Phase 3 involved the production of a box of teaching and learning resources for schools on the theme of sustainable consumption, specifically "energy, waste and pollution". This was so that the trainee teachers' lesson plans and resources made in phase 1 could be re-used by other teachers and learners in other schools. In addition, books about waste, energy and pollution and a film (Wall-E) was purchased through public external funding ${ }^{7}$.

Dissemination was sought through digital means namely contact through pre-existing educational and environmental networks in the Barcelona area. Dissemination also included the creation of a blog, entitled "A Better World / Un Mon Millor" (https://betterworldschools.com/) by the teacher trainer and a university student assistant where trainee teachers could have their (unpiloted) lesson plans and resources uploaded. This resource was also shared with other students in the Education faculty of the same university from other years so that they could also contribute to it and use them.

\section{Discussion}

T he project, from its conception to the realization through the different phases, showed how a number of conceptual frameworks pertaining to sustainability could be combined with complementary pedagogical approaches to create a project that was "collaborative", "action-oriented" and "transdisciplinary" in nature (Junyent, Cebrián and Mulà, 2018). The conceptual frameworks of Junyent and Cebrián $(2014 ; 2015)$ supported the creation of the project in order to develop key sustainability competencies. In addition, the project showed how:

1. language learning approaches namely task-based, projectbased learning and CALL could be successfully combined;

2. the dual focus of language learning and content learning (the content) can be integrated with the use of digital and non-digital tools (the means);

3. projects could work across educational levels (in this case a school and a university) in a transdisciplinary way; and

4. human and digital networks were utilized collaboratively for transferring knowledge, and creating and sharing resources for re-use.

While this project focused on the collaborative efforts between a university and school for shared common goals and purposes, the results echo Levy, Gimeno, Barr and Blin's (2015) point about the importance of collaborative endeavours between teams that go beyond individual institutions and national borders. Not only do such collaborative efforts strengthen the ongoing sustainability of CALL (Levy, Gimeno, Barr and Blin, 2015) but such collaboration can sustainably support the teaching of issues about sustainability using CALL.

The project adds to previous practical examples of teaching and learning activities and materials developed by English teachers such as those showcased by Maley and Peachey (2017). The project also highlights how computer use cannot only be integrated as a small element in the teaching about sustainability issues, but can also be an underpinning sustainable thread within it. Furthermore, it highlights how computers can be used as a "means of implementation" to achieve the SDGs as it cuts across all SDGs. Finally, technology use, specifically tools for CALL, can also successfully support sustainability competencies. These competencies, according to Junyent, Cebrián and Mulà (2018) can be developed through self-directed learning, participation and collaboration with partners within and beyond the institution. These aspects characterized the project across the phases, particularly phases 1 and 2 .

Although phase 3 was not the focus of this paper, the materials and activities piloted in phase 2 have been collated in order that other teachers and schools can borrow them free of charge. This is with the aim of extending participation and collaboration between teachers and schools as well as to 


\section{${ }^{66}$ While this project focused on the collaborative efforts between a university and school for shared common goals and purposes, the results echo Levy, Gimeno, Barr and Blin's (2015) point about the importance of collaborative endeavours between teams that go beyond individual institutions and national borders.}

facilitate a wider reuse of teaching and learning resources. These are to accompany books, films and objects such as a globe that teachers can also borrow. Lesson plans and resources that accompany the books have also been made available through the blog. This is in order that the re-usability of resources might be extended across Barcelona. The results of the project could not be achieved without collaboration through adoption and adaptation- or transferability across contexts through sharable designs as highlighted by Levy, Gimeno, Barr and Blin (2015).

Finally, it is important to note that all aspects of sustainability might not be able to be addressed in any one project (from a teacher trainer perspective). Another action research cycle involving reflection on the part of the trainee teacher could aim to identify how different facets of the project could be more sustainable.

\section{Limitations}

This project focused on the "use of" digital technologies for leveraging or harnessing support for achieving SD goals. However, future teachers and schools may also want to consider the "consumption of" technologies which implies addressing issues of purchasing and life span of the tools purchased. As digital technologies become more powerful, they become obsolete quicker than older versions and can also have a shorter shelf life as schools reach for the latest gadgets as products. This is important because teachers and schools that wish to use digital technologies should conceivably reflect on this aspect of sustainability as it can lead to e-waste (Ng \& Nicholas, 2013; De Jager, 2015). Chromebooks for example, a popular purchase in many schools, have a limited lifespan. This means that there is a point at which they will no longer receive software updates or they can become an insecure system within four to five - or even six and a half years - (Raphael, 2019) although newer Chromebook models have a lifespan of eight years according to Google (Hodge, 2020). This highlights that digital technology "use" must come from a holistic understanding beyond simply their use to include consumption and lifespan as sustainability issues. This means that educational institutions cannot validate the outcome or Return On Investment (ROI) in information technologies in terms of a simple input-output analysis. In this sense, schools and universities as institutions might also become agents of change in this respect, as such important purchasing decisions are typically beyond an individual teacher's remit or control.

\section{Acknowledgments}

I would like to acknowledge Baixeras School in Barcelona for their commitment to education for sustainability in the everyday experiences of the children who attend the school. I particularly thank Deborah Castel-Hughes and Maria Vallès in collaborating on this project and dedicating time to see it through. I also thank the headteacher, MercèVilalta i Miquel and all the other members of staff who were encouraging in the project's evolution. I thank Andrew Rance (at the UIC) for discussing and offering fun and innovative ideas for the project and for translation support for the trainee teachers. Finally, I would like to acknowledge the work of Beatriz Pérez Manén and thank her for her significant role in creating the blog.

I also thank and acknowledge the Council of Barcelona (Ajuntament de Barcelona) for funding phase 3 of the project so that other primary school teachers and children in Barcelona can benefit from its outcomes.

\section{Notes}

1 The components were originally published in Spanish in 2014 and subsequently published in English in 2015.

2 The reflection was that after piloting the project between university students and school children it was fitting to make the teaching and learning materials created for schools re-usable by other teachers and learners.

3 A visual representation of this model for teachers can be found on page 23 of Methodology in Language Learning T-kit by Curran, P. (2006). Strasbourg, France: Council of Europe. Available at https://pjp-eu.coe.int/ documents/42128013/47261185/tkit2.pdf/3ef38319-220b474f-8960-8c0e1ae62444

4 Link to the plurilingual glossary on Sustainable consumption can be found here: https://docs.google.com/ document/d/1LKX-evje44f29TEr6PNiq9jQRFxkNZE6ndX5w HgefaY/edit?usp=sharing 
5 However, in subsequent courses that have adopted these two phases (i.e. with pre-service teachers in their $3^{\text {rd }}$ year), university students were able to carry out their own task sequences in the school, which the author deems as having more transformative potential for preservice teachers.

6 These were put together as a "pack" and made available to teachers of the school. From this process, the idea for phase 3 emerged - an idea that would involve other schools in Barcelona.

7 External funding for phase 3 was kindly provided by the Ajuntament de Barcelona (Barcelona Council).

\section{References}

Cebrián, G., Junyent, M. (2014). Competencias profesionales en Educación para la Sostenibilidad: Un estudio exploratorio de la visión de futuros maestros. Enseñanza de las Ciencias, 32, 29-49.

https://doi.org/10.5565/rev/ensciencias.877

Cebrián, G., \& Junyent, M. (2015). Competencies in education for sustainable development: Exploring the student teachers" views. Sustainability, 7(3), 2768-2786. https://doi.org/10.3390/su7032768

Council of Europe. Council for Cultural Co-operation. Education Committee. Modern Languages Division. (2001). Common European Framework of Reference for Languages: learning, teaching, assessment. Cambridge University Press.

Curran, P. (2006). Methodology in language learning T-kit. Council of Europe.

De Jager, T. (2015). A Proposal to Integrate the Management of Electronic Waste into the Curriculum of Primary Schools. Eurasia Journal of Mathematics, Science and Technology Education, 11(3), 443-454.

https://doi.org/10.12973/eurasia.2015.1340a

Dewey, J. (2011). Democracy and Education. Milton Keynes: Simon and Brown.

Ellis, R. (2009). Task-based language teaching: Sorting out the misunderstandings. International journal of applied linguistics, 19(3), 221-246.

https://doi.org/10.1111/j.1473-4192.2009.00231.x

Fadeeva, Z., Mochizuki,Y., \& Wals, A. E. (2010). Mirroring, Gestalt switching and transformative social learning: stepping stones for developing sustainability competence. International Journal of Sustainability in Higher Education, 11(4), 380-390.

https://doi.org/10.1108/14676371011077595

Hodge, R. (2020, January). New Chromebooks get lifespan boost to 2028. CNET. Retrieved 21 September 2020. https://www.cnet.com/news/new-chromebooks-to-getlifespan-boost/

Hutchinson, T., \& Waters, A. (1987). English for specific purposes. Cambridge university press.

https://doi.org/10.1017/CB09780511733031

International Telecommunications Union (2017). Fast Forward Progress Report-Leveraging Tech to achieve the global goals. https://www.itu.int/en/sustainable- 


\section{world/Pages/report-hlpf-2017.aspx}

Johnson, A. P. (2010). Three Views of teaching: Transmission, Transaction, and, Transformation, in Making Connections in Elementary and Middle School Social Studies, $2^{\text {nd }}$ edition. Sage Publishing.

Junyent, M., Cebrián, G., \& Mulà, I. (2018). Special Issue "Competencies in Education for Sustainable Development". Call for papers. https://www.mdpi.com/ journal/sustainability/special issues/Competencies ESD

Levy, M., Gimeno Sanz, A. M. G., Barr, D \& Blin, F. (2015). Introduction. In A. M. G. Sanz, M. Levy, F. Blin \& D. Barr (Eds.). World CALL: Sustainability and computerassisted language learning. Bloomsbury Publishing.

Luchs, M. G., \& Miller, R. A. (2015). Consumer responsibility for sustainable consumption. In L. A. Reisch \& J. Thøgersen (Eds.), Handbook of research on sustainable consumption. Edward Elgar Publishing.

https://doi.org/10.4337/9781783471270.00027

Maley, A., \& Peachey, N. (Eds.). (2017). Integrating global issues in the creative English language classroom: With reference to the United Nations Sustainable Development Goals. British Council.

Miller, J. P. (1996). The Holistic Curriculum. OISE Press.

Mochizuki, Y., \& Fadeeva, Z. (2010), Competences for sustainable development and sustainability: Significance and challenges for ESD. International Journal of Sustainability in Higher Education, 11(4), 391-403.

https://doi.org/10.1108/14676371011077603

Ng, W., \& Nicholas, H. (2013). A framework for sustainable mobile learning in schools. British Journal of Educational Technology, 44(5), 695-715.

https://doi.org/10.1111/j.1467-8535.2012.01359.x

Nunan, D. (1989). Designing tasks for the communicative classroom. Cambridge University Press.

Nygaard, C., Courtney, N., \& Holtham, C. (2011). Effectiveness in higher education demands innovations in teaching that progress beyond transmission. In C. Nygaard, N. Courtney \& C Holtham (Eds.), Beyond transmission: Innovations in university teaching, pp. 1-10. Libri Publishing.

Raphael, J. R. (2019, October). It's time to rethink the Chrome OS upgrade standard. Computer World. Retrieved 30 Oct 2019. https://www.computerworld.com/article/3442676/ chrome-os-upgrade-standard.html
Reason, P., \& Bradbury, H. (Eds.). (2006). Handbook of action research (concise paperback ed.). Sage.

Santrock, J. W. (2004). Educational Psychology. Second edition. McGraw-Hill.

Sanz, A. M. G., Levy, M., Blin, F., \& Barr, D. (Eds.). (2015). World CALL: Sustainability and computer-assisted language learning. Bloomsbury Publishing.

Sipos, Y., Battisti, B., \& Grimm, K. (2008), Achieving transformative sustainability learning: engaging heads, hands and heart. International Journal of Sustainability in Higher Education, 9(1), 68-86.

https://doi.org/10.1108/14676370810842193

Stibbe, A., (Ed.) (2009). The Handbook of Sustainability Literacy: Skills for a Changing World. Green Books.

Stringer, E. T. (2008). Action research in education. Pearson Prentice Hall.

Svanström, M., Lozano-García, F. J., \& Rowe, D. (2008). Learning outcomes for sustainable development in higher education. International Journal of Sustainability in Higher Education, 9(3), 339-351.

https://doi.org/10.1108/14676370810885925

Toomey, A. H., Markusson, N., Adams, E., \& Brockett, B. (2015). Inter- and transdisciplinary research: A critical perspective. Submitted to Global Sustainable Development Report Chapter 7 Policy Brief. Retrieved from: https://sustainabledevelopment.un.org/ content/documents/612558-Inter-\%20and $\% 20$ Transdisciplinary $\% 20$ Research $\% 20-\% 20 \mathrm{~A} \% 20 \mathrm{Critical} \% 20$ Perspective.pdf

UN General Assembly. (2015). Transforming Our World: The 2030 Agenda for Sustainable Development. Resolution adopted by the General Assembly on 25 September 2015. A/RES/70/1. New York: United Nations. Retrieved 22 September 2020 https://sustainabledevelopment.un.org/ content/documents/21252030\%20Agenda $\% 20$ for $\% 20$ Sustainable\%20Development\%20web.pdf

Willis, J. (1996). A Framework for Task-Based Learning. Longman. 


\section{Appendix A}

Project introduction and instructions

https://docs.google.com/document/d/1ahMT8MH5YLj5RBct_8r4a7v2u4a7clP10JGIoCS7-Bg/edit?usp=sharing

\section{Appendix B}

Post task activity for children aimed to develop future/alternative scenarios

\section{My sustainable Barcelona}

What does a sustainable Barcelona look like? Does it have cars or bicycles? Is there pollution in the sky or is it clean? Is there waste on the street or do people recycle? Draw what you imagine. You can use your poster to help you. 


\section{Appendix C}

Lesson plan

TBLL planning template 2 (Willis model)

AUTHOR: Janine Knight

\section{LEARNER AGE/ENGLISH LEVEL: \\ 2nd Primary}

A1-B1

CONTENT, THEME OR TOPIC:

Sustainable Consumption

\section{PREVIOUS KNOWLEDGE AND/OR EXPERIENCES NEEDED:}

Children understand some principles about materials that can be recycled or not, as they are asked and taught to use other means to wrap their snacks in, rather than aluminum foil. This idea is elaborated in a project in P5 about the "foil monster" before they arrive at Primary school.

The school is a "green school": they are signed up to the Catalan government's "escoles verdes" campaign. The children experience recycling through the creation of art works in many of their classes.

The class is International in the sense that many parents were born outside of Catalunya. Therefore, some children already understand and/or speak English as an additional or heritage (parental) language. The child understand basic questions such as "what is it"? but most need scaffolding for more complex questions such as "where do we live"?

\begin{tabular}{|l|l|l|}
\hline \multicolumn{1}{|c|}{ Objectives } & \multicolumn{1}{|c|}{ Content } & \multicolumn{1}{c|}{ Evaluation criteria } \\
\hline $\begin{array}{l}\text { Identify some of the problems that the } \\
\text { earth faces with respect to sustainable } \\
\text { living (awareness) }\end{array}$ & Problems humans and the earth face & $\begin{array}{l}\text { Can match the problem word with the } \\
\text { problem picture i.e. energy, pollution, } \\
\text { waste }\end{array}$ \\
\hline $\begin{array}{l}\text { Classify which purchases, usage and } \\
\text { disposal habits are more sustainable than } \\
\text { others (decision making and actions) }\end{array}$ & $\begin{array}{l}\text { Sustainable purchases, usage and disposal } \\
\text { habits that are more or less sustainable }\end{array}$ & $\begin{array}{l}\text { Can point and/or say which usage, } \\
\text { purchase or waste disposal method (out } \\
\text { of a choice of two) is better for the planet } \\
\text { and why } \\
\text { Can classify images of purchases, usage } \\
\text { and disposal habits according to whether } \\
\text { they are more or less sustainable }\end{array}$ \\
\hline $\begin{array}{l}\text { Present a future/alternative scenario } \\
\text { visioning (post task) }\end{array}$ & Future sustainable scenarios & $\begin{array}{l}\text { Can represent what a future scenario of a } \\
\text { sustainable Barcelona looks like e.g. with } \\
\text { recycling bins, with cycles, trees etc.. }\end{array}$ \\
\hline
\end{tabular}

\begin{tabular}{|l|l|l|}
\hline \multicolumn{1}{|c|}{ LANGUAGE OBJECTIVES AND EVALUATION CRITERIA } \\
\hline \multicolumn{1}{|c|}{ Objectives } & \multicolumn{1}{|c|}{ Content } & \multicolumn{1}{c|}{ Evaluation criteria } \\
\hline $\begin{array}{l}\text { Understand and identify some of the } \\
\text { problems that the earth faces with respect } \\
\text { to sustainable living (awareness) }\end{array}$ & Problems humans and the earth face & $\begin{array}{l}\text { Can recognize familiar words and very } \\
\text { basic phrases concerning concrete } \\
\text { surroundings and personal relevance } \\
\text { (LISTENING A1-B1) } \\
\text { Can read and match 3 keywords and } \\
\text { match them to the corresponding image } \\
\text { (READING A1) }\end{array}$ \\
\hline
\end{tabular}




\begin{tabular}{|l|l|l|}
\hline $\begin{array}{l}\text { Classify which purchases, usage and } \\
\text { disposal habits are more sustainable than } \\
\text { others (decision making and action) }\end{array}$ & $\begin{array}{l}\text { Sustainable purchases, usage and disposal } \\
\text { habits that are more or less sustainable }\end{array}$ & $\begin{array}{l}\text { Can point and/or say which usage, } \\
\text { purchase or waste disposal method (out } \\
\text { of a choice of two) is better for the planet } \\
\text { and why (SPOKEN INTERACTION-NATIVE } \\
\text { LANGUAGE AND/OR ENGLISH A1-B2) }\end{array}$ \\
\hline $\begin{array}{l}\text { Identify key words pertaining to the topic } \\
\text { of sustainability (post task) }\end{array}$ & & $\begin{array}{l}\text { Can identify words in a word search related } \\
\text { to sustainable consumption. e.g. earth } \\
\text { (READING A1) }\end{array}$ \\
\hline
\end{tabular}

\section{CONTENT OBLIGATORY LANGUAGE}

\section{Vocabulary}

1. Pollution: masks, chemicals, sky, sea, transport, cars, bicycle, walking.

2. Energy: less energy/more energy, light on, light off, lots of, mobiles, computers.

3. Waste - Re-use - Recycle plastic, cloth, sandwich wrap, foil, shampoo bar, shampoo bottle, metal bottle, plastic bottle.

Planet Earth, look after, care for

\section{DEVELOPMENT}

(Duplicate cells as needed)

\section{APPENDICES}

(List/description of materials included)

\section{Structures}

Is more/less sustainable than...

Better for the planet Earth

\begin{tabular}{|l|l} 
& \begin{tabular}{c} 
using APA 6th edition style) \\
other books, websites, etc. for inspiration, \\
\hline
\end{tabular}
\end{tabular}

\section{PRE-TASK}

\section{Description:}

Introduction to looking after the earth teacher mimes

Using the globe as a prompt, teacher asks: Where do we live? Do we live in Africa? Do we live in Australia, Do we live in America? Where do we live? Children explain and $T$ and $\mathrm{S}$ look on globe together

$\mathrm{T}$ introduce the $3 \mathrm{BIG}$ problems that we need to solve

T put flashcards 'problem 1', 'problem 2' and 'problem 3' on the wall.

Using the picture cards as clues, $T$ elicit what the children think the problems are, one by one. Finally, T presents children with 'word cards' with 'energy', 'pollution' and 'waste' on and children have to match the problem words with the pictures/ problems.

$\mathrm{T}$ and $\mathrm{S}$ read and say aloud the three problems. T says that she wants to go shopping and using objects and pictures asks children to say which object/action is better for the planet Earth and why. Teacher use examples to model classifying e.g. using a car or bicycle?, leave the light on or off..? using a plastic bag or a cloth bag? using foil or a sandwich wrap. T let the child have the object/image if they guess correctly.

\subsection{Materials for students:}

\subsection{Materials for teacher:}

- globe

- big flashcards with 'problem 1?', 'problem 2?' and 'problem 3?' on the wall.

- big picture flashcards (2 or 3) for each problem

- big word cards for each problem:

'energy', 'pollution', 'waste'

\section{Objects and images:}

- plastic vs cloth bag (object)

- metal flask vs (one use) plastic bottle

- shampoo bar vs shampoo bottle (object)

- foil vs paper sandwich bag (object)

- lots of lights on or switch off (image)

- bicycle or car use (image)

- fruit and vegetables with packaging on or without packaging (image) 
Interaction/grouping: Group of 10-13

Timing: $10 \mathrm{~min}$

\section{TASK preparation}

\section{Description:}

Teacher explain that the children are going to make a poster about our actions and objects we use that are better for the planet earth. T mime thumbs up and looking after globe.

T show $\mathrm{S}$ little cards in an envelope and start to classify with them e.g. Which is more sustainable (thumbs up) or less sustainable (thumbs down) for the planet Earth? Ss start to classify using the little cards (whole group).

Task children to now work in pairs and make their own posters, classifying their own picture cards in their envelopes.

Interaction/grouping: Group of 10-13

\subsection{Materials for students:}

\subsection{Materials for teacher:}

- empty poster with 'more sustainable' and 'less sustainable' on each side.

- big poster paper

- model of poster (frame for classifying)

- envelope of little cards to classify

Timing: 5 min

\section{TASK (Classification)}

\section{Description:}

Children work in small groups making their own posters. They have to decide which actions, purchase or use of objects are more/less sustainable.

Teacher circulate around the groups discussing what children have decided and confirming if they are all correct.

\subsection{Materials for students:}

- small cards in an envelope, each with a more or less sustainable option on each side

- dig poster paper

- 13 glue sticks

- 13 scissors

- coloured pens

\subsection{Materials for teacher:}

\section{Interaction/grouping: Groups of 2-3}

Timing: $30-35 \mathrm{~min}$

\section{POST TASK(S)}

\section{Description:}

Children can choose from doing a word search with the key words on and/or create their own drawing of 'My sustainable Barcelona'

\subsection{Materials for students:}

- Handouts

- Coloured pens

\subsection{Materials for teacher:}

Interaction/grouping: Individual

Timing: 5-10 min 


\section{Appendix D}

Problem Flashcards integrated as part of the pre-task activities

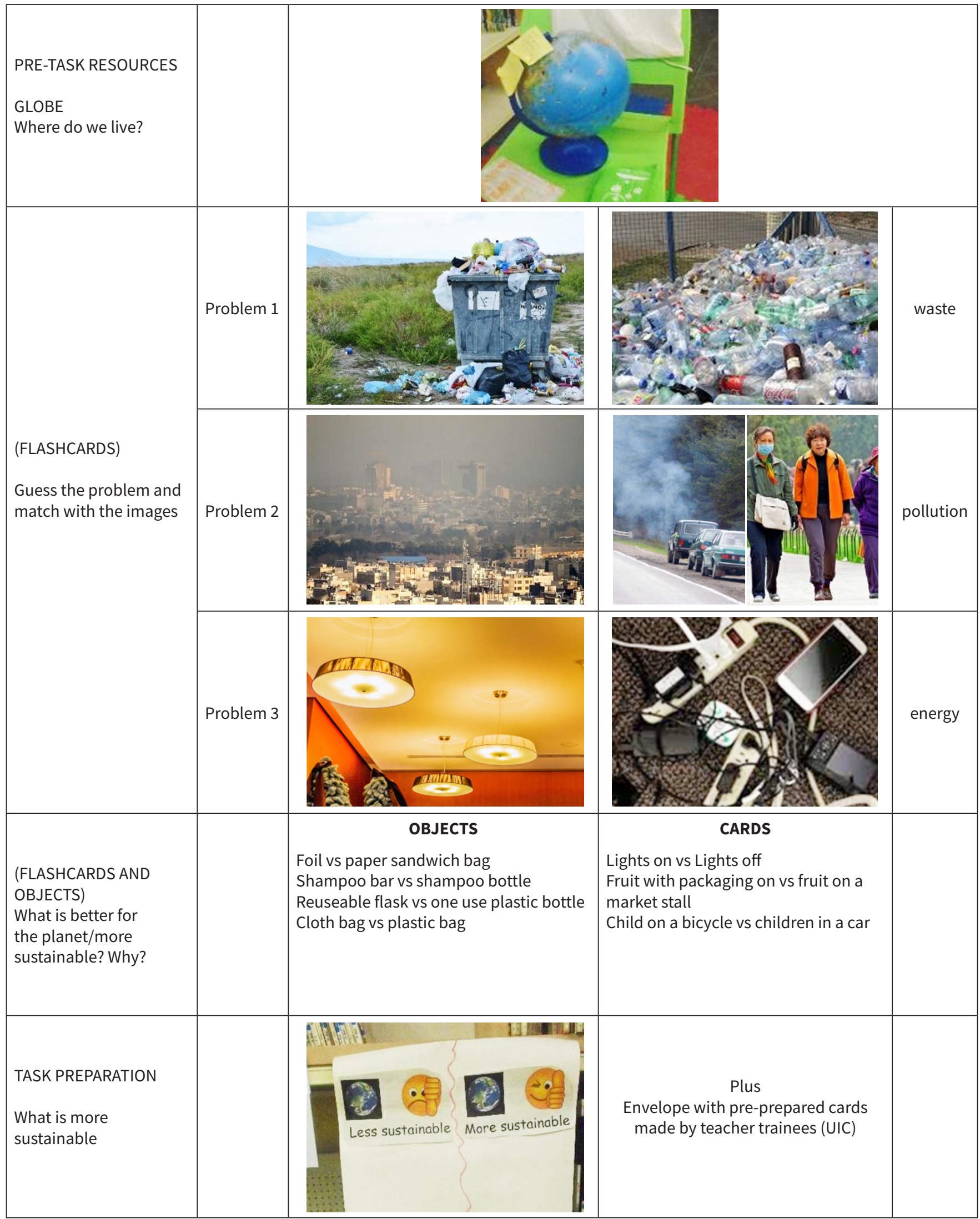

